\title{
THE EFFECT OF PUCCINIA KOMAROVII TRANZSCH. INFECTION ON CHARACTERS OF IMPATIENS PARVIFLORA DC. IN GALIO SYLVATICI-CARPINETUM (R. Tx. 1937) OBERD. 1957 FOREST ASSOCIATION
}

\author{
Renata PiskorZ, MatgorZata Klimko \\ Department of Botany, August Cieszkowski Agriculture University \\ Wojska Polskiego 71c, 60-625 Poznań, Poland \\ e-mail: reniapis@au.poznan.pl
}

(Received: May 31, 2005. Accepted: December 20, 2005)

\begin{abstract}
The aim of the present study was to determine how internal diversity of oak-hornbeam forest modifies the course and effects of infestation of small-flowered balsam (Impatiens parviflora) with rust Puccinia komarovii. The study investigated the effect of the disease on the demography of the population, and the habit and biomass allocation of the infested specimens, as well as the initiation of non-specific defense mechanisms.

It was shown that: 1) the percentage of infected specimens was independent of the undergrowth-coverage rate and of the I. parviflora density; 2) infected populations differ from healthy ones in the seasonal dynamics of abundance changes; 3 ) high mortality is observed as early as May and the first part of June, i.e. it pertains to specimens, which did not begin reproduction; 4) the presence of infection and its intensity stimulate the growth of the stem and the hypocotyl; 5) fresh weight of infected specimens is by almost $30 \%$ lower in comparison to the weight of uninfected plants; the weight of badly infected plants decreases by $20 \%$ in comparison to the less severely infected balsam plants; the weight of generative organs drops most significantly, even by over 50\%; 6) biomass allocation does not fluctuate considerably; 7) reproduction effort expressed by the ratio of the weight of fruits (or only seeds) to the total biomass shows a distinct downward trend; 8) the environmental factor does not affect the force of defense mechanisms, the strength of biochemical response of diseased plants depends on the degree of their infestation.
\end{abstract}

KEY WORDS: Impatiens parviflora, Puccinia komarovii, oak-hornbeam forest, disease, demographic effects, biomass allocation, physiological host-pathogen interaction.

\section{INTRODUCTION}

Since a long time the relationship between fungus parasite and host plant has been studied in cultivation. These studies concerned tractability of agricultural plant varieties to disease and the effect of disease on plant harvest. Some few investigations carried on wild plant populations indicate, that the fungi influences plant demography, morphology and hardiness (Burdon 1987; Clay 1990; Eliáš 1995; Harper 1977; Lembicz 1996; Pańka 2004).

The Asian plant of small-flowered balsam (Impatiens parviflora) has been found in Europe for over 160 years. The naturalization of this species in the new continent is evidenced among others by the fact that it enters into numerous interrelationships with fungi, plants and animals living on the continent (Daumann 1967; Hegi 1965; Schmitz 1998; Stary, Laska 1999; Trepl 1984). At the same time, through balsam plants also other organisms, previously not found here, have been imported to the new habitat (Sta- cherska 1972). One of them is the fungus Puccinia komarovii.

Puccinia komarovii originated from Central Asia and the northern Himalayas, where it parasitizes on Impatiens parviflora and Impatiens amphorata Edgew. The crossing of the geographical boundary occurred in the early 20th century, probably through seeds of Impatiens parviflora mixed with the fungus (Savich 1957). In 1921 the analyzed species was found in Kiev, in 1933 in Berlin, in 1937 in Riga, in 1938 in Copenhagen, and in 1940 in Salzburg (Rauhala 1951 after Trepl 1984; Sydow, Sydow 1935; Trepl 1984). In Poland it has been reported since 1934, the first stands were found in Silesia and in Beskidy. Puccinia komarovii is at present considered a common species throughout Poland (Majewski 1979). In Europe it is considered an invasion species (Bacigálová, Zlochová 2001).

The aim of the presented investigations was to determine how the internal diversity of oak-hornbeam forest modifies the course and effects of rust infection. The effect of the 
disease was investigated on demography of the population and the habit and biomass allocation of the infected specimens, as well as the initiation of non-specific defense mechanisms.

\section{METHODS}

The investigations were conducted in the Wielkopolski National Park. In forest sector 136 permanent plots of $3 \times 5 \mathrm{~m}$ were established. The sites of the plots reflected the internal diversity of the oak-hornbeam forest Galio sylvaticiCarpinetum (Table 1).

Field observations were conducted for 3 years. At the turn of July and August the diseased and healthy specimens, growing in the plots of $1 \times 1 \mathrm{~m}$ incorporated into permanent study plots, were counted. At the same time, the coverage rate with undergrowth plants was recorded for each plot. On the basis of the collected data statistical analyses (Pearson correlation) were performed to find whether undergrowth density and the density of small-flowered balsam had a significant effect on the percentage of diseased specimens. In one year additionally the percentage of specimens with mild and severe disease symptoms were recorded, which was the simplest method to assess the intensity of the disease. Plants in which whole leaf blades were covered by uredia, telia and numerous yellow discolorations of leaf tissues were considered to exhibit severe disease symptoms.

Selected elements of demography of the infected balsam population were recorded during two seasons. Changes in density of Impatiens parviflora were investigated in experimental plots A-F. In one year in plots of $1 \times 3 \mathrm{~m}$, established within permanent plots A-F more detailed observations were undertaken on changes in the number of plants in the period from seed germination to the full generative development of the specimens. From April to June observations were conducted at weekly intervals, whereas in June and July at the intervals of two or three weeks. Each time the number of balsam plants, the percentage of speci- mens with rust infection symptoms and dates of entering the generative phase by the first balsam plants were recorded along with remarks concerning distinct changes in the Impatiens parviflora habitat.

In moderately shaded sites 30 diseased and 30 healthy specimens were selected. Due to the difficulties in collecting the sample containing healthy balsam plants from gaps in the tree stand, 30 severely infected and 30 mildly infected plants were selected. The size of the sample was determined after Abrahamson and Hershey (1977). The length of the stem and the diameter of the hypocotyl were measured on living plants and the leaves, flowers and fruits were calculated on each of the selected plants. Immediately after the plants were collected their fresh weight was determined. Roots, stems and leaves of the collected plants were weighed using a WPE 600 balance (up to $600 \mathrm{~g}$ ), flower buttons and flowers were weighed on a WPE 30 electronic balance (up to $30 \mathrm{~g}$ ), while fruits - on a WPA 60/C/1 electronic balance (up to $60 \mathrm{~g}$ ).

The presence of Puccinia komarovii on Impatiens parviflora was documented in the form of binocular macrophotography and microphotographs taken under a SEM.

Resistance mechanisms of Impatiens parviflora were investigated on rust spots on leaves in order to determine the range of metabolic response of plants. Peroxidase activity, the release of $\mathrm{H}_{2} \mathrm{O}_{2}$ and the lignification of cell walls were determined. The investigations were conducted in two variants:

1. Release of active oxygen forms is usually a short-term process, thus in order to detect the occurrence of this metabolic reaction a sample of 30 plants with mild disease symptoms was collected, selecting specimens from all the plots. Observations were conducted on two leaves from each plant.

2. In order to check whether environmental factors modify the strength of defense mechanisms, ten diseased specimens were selected at random from each experimental plot. Observations were conducted on two leaves from each plant.

The presence of $\mathrm{H}_{2} \mathrm{O}_{2}$ was detected according to Thordal-Christensen et al. (1997). A water solution of DAB

TABLE 1. Characterization of research plots.

\begin{tabular}{|c|c|c|c|c|}
\hline Plot symbol & Character of phytocoenosis & $\begin{array}{l}\text { Tree canopy density } \\
\text { and light condition }\end{array}$ & Soil moisture \% vol. & $\mathrm{C}: \mathrm{N}$ \\
\hline A & $G s-C$; best preserved patch & $\begin{array}{l}a_{1} 90 \% \\
a_{2}- \\
b-\end{array}$ & 37.69 & 16.64 \\
\hline B & Gs-C with I. parviflora domination & $\begin{array}{l}a_{1} 35 \% \\
a_{2} 20 \% \\
b-\end{array}$ & 24.96 & 15.50 \\
\hline $\mathrm{C}$ & $G s-C$ with I. parviflora domination & hallow & 17.99 & 17.93 \\
\hline $\mathrm{D}$ & Gs-C well preserved patch & hallow & 33.76 & 13.50 \\
\hline $\mathrm{E}$ & $G s-C$ with massive occurrence of Carpinus betulus seedlings & $\begin{array}{l}a_{1} 10 \% \\
a_{2}- \\
\text { b } 20 \%\end{array}$ & 31.75 & 19.20 \\
\hline $\mathrm{F}$ & Contact zone in Gs-C ecotone with Calamagrostio-Quercetum & $\begin{array}{l}a_{1} 5 \% \\
a_{2}- \\
\text { b } 5 \%\end{array}$ & 16.80 & 18.43 \\
\hline
\end{tabular}



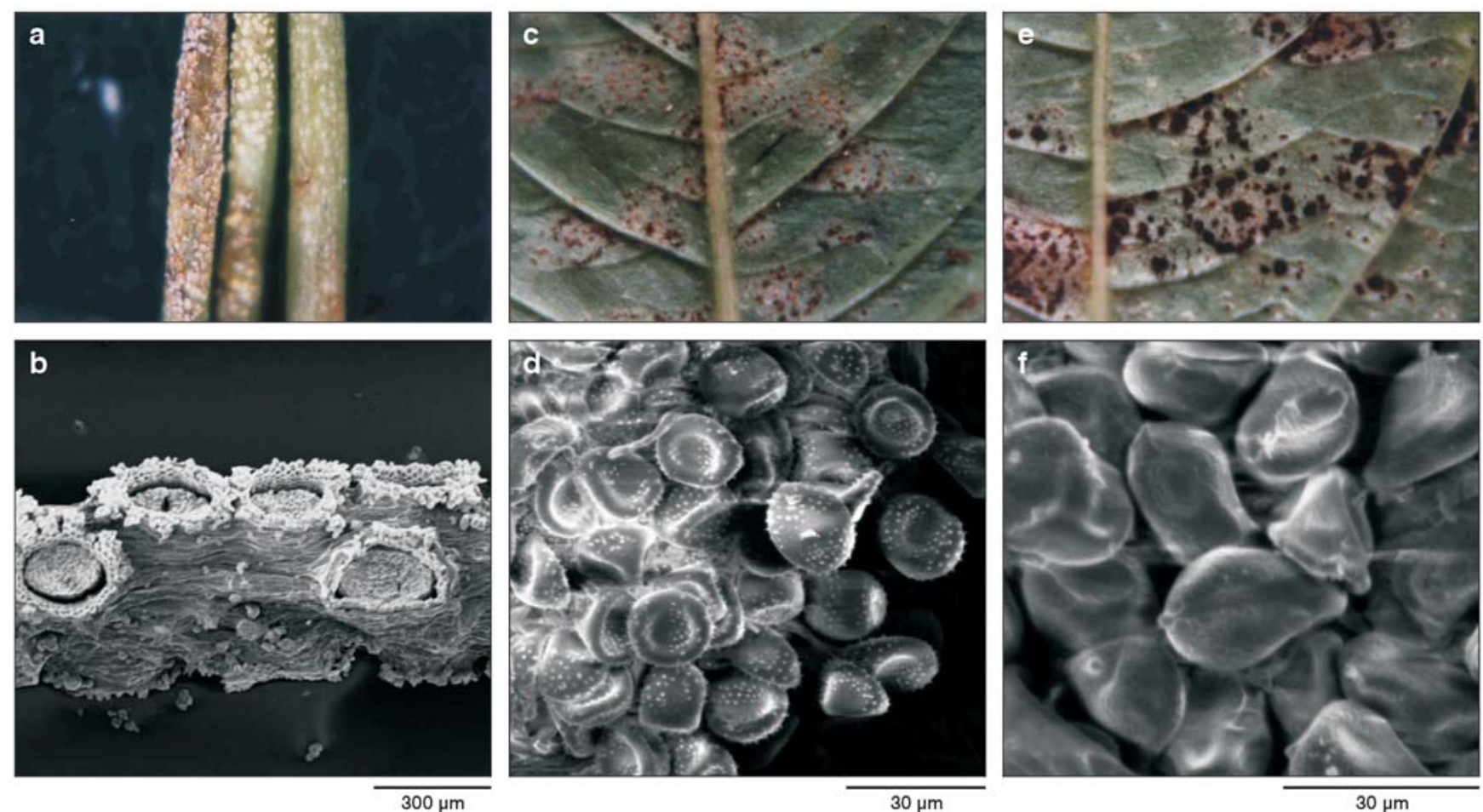

Fig. 1. Puccinia komarovii on Impatiens parviflora. a, b - aecidia; c, d - uredia; e, f - telia.

$\left(1 \mathrm{mg} \cdot \mathrm{ml}^{-1} \mathrm{H}_{2} \mathrm{O}\right.$ ) was prepared adding $1 \mathrm{M} \mathrm{HCl}$ dropwise until DAB-HCl of $\mathrm{pH} 3.8$ was produced. Such solution was poured into Petri dishes, in which the leaves were placed. Leaves were taken out of the solution after $12 \mathrm{~h}$, washed in distilled water and chlorophyll was removed in boiling $96 \%$ ethanol heated in a water bath. The appearance of redbrown color on the leaves indicated the presence of hydrogen peroxide.

Peroxidase activity was determined according to Thordal-Christensen et al. (1997). To the DAB-HCl solution of $\mathrm{pH} 3.8$, prepared as described above, $2 \mathrm{M} \mathrm{NaOH}$ were gradually added in order to increase $\mathrm{pH}$ of the solution to 5.8. Each leaf was flooded with such solution with the addition of $2.5 \mathrm{ml}$ water solution of $1.0 \mathrm{mM} \mathrm{H}_{2} \mathrm{O}_{2}$. The presence of peroxidases was evidenced by the appearance of polymerized DAB in the form of red-brown coloring.

The in vivo lignin detection was carried out according to Milosevic and Slusarenko (1996). Leaves were placed for $12 \mathrm{~h}$ in $25 \mathrm{ml} \mathrm{1 \%}$ phloroglucin solution in $70 \%$ ethanol. Next leaves were rinsed twice in distilled water and placed for a moment in $30 \% \mathrm{HCl}$. The occurrence of red-orange coloring indicates the presence of lignins.

\section{RESULTS}

\section{Symptoms of Puccinia komarovii infestation}

The whole life cycle of Puccinia komarovii occurs on one host. Rust development takes place in two phases: the vegetative stage (mycelium) and the sporulating stage (Chester 1946; Joseph 1929). Detailed descriptions of the sporulating stage were given e.g. by Bacigálová et al. (1998), Buhr (1964), Majewski (1979), and Sydow and Sydow (1904).

In infected balsam plants in the Wielkopolski National Park aecidia appeared in the period from May to June.
They are found on the stem, less frequently on the petiole and the underside of cotyledon blades - they often cause calluses and deformations of the hypocotyl (Fig. 1a, b). Uredia may be observed as early as June on the underside of leaf blades; they take the form of small light brown clusters (Fig. 1c, d). They are accompanied by indistinct yellowish spots on the upper part of leaves. Apart from uredia, concentrically distributed chestnut brown sporing telia develop in July and August (Fig. 1e, f).

\section{The effect of the disease on the demography of balsam plants}

During the three years of observations no such phytocenosis patches were found, in which all the specimens were free from the fungal parasite. Statistical methods showed that the percentage of infected specimens was independent of the undergrowth-coverage rate and of the density of Impatiens parviflora. However, at density of balsam plants above 90 specimens $/ \mathrm{m}^{2}$ the percentage of diseased specimens was always above $90 \%$. At density below 90 plants $/ \mathrm{m}^{2}$ the percentage of infected plants varied considerably, ranging from 0 to $100 \%$ (Fig. 2).

The frequency of infested specimens varied depending on site conditions, under which Impatiens parviflora was developing (Fig. 3). The smallest percentage of such specimens was found in experimental plot $\mathrm{D}$, while slightly higher - in plots A and E. The highest number of plants infested by the fungus, i.e. approx. 95\% all specimens, was reported in plot C. A high (B) and very high (C) percentage of infected balsam plants is connected with very high density of this species, as has been mentioned earlier. In all the experimental plots the ratio of infected and healthy specimens during the three successive years of observations was similar and the maximum seasonal variation was $20 \%$. Fungal infection developed with varying intensity in individual plots, but in all the sites severely and moderately in- 


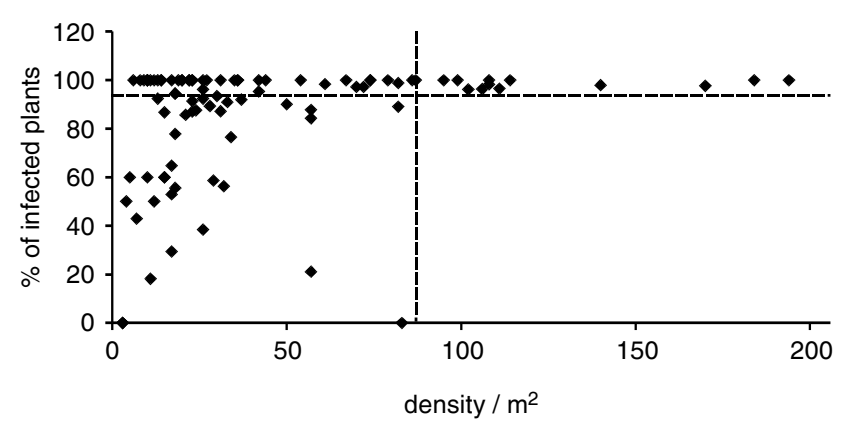

Fig. 2. The influence of Impatiens parviflora density on the participation of infected specimens by Puccinia komarovii.

fected specimens were found. The percentage of severely infected specimens varied considerably, ranging from approx. $30 \%$ (D) to approx. $70 \%(\mathrm{~B}, \mathrm{C})$.

Investigations showed that there is a dependency between the percentage of all infected specimens and the severity of infection (Fig. 4). Balsam was more moderately infected in the ecotone zone than in the oak-hornbeam forest, as was indicated by the considerable percentage of moderately infected plants in comparison to the total percentage of infected plants.

Infected populations of Impatiens parviflora differ from healthy populations in the seasonal dynamics of population size. In figure 5 the results of the investigations, conducted by the authors of this study in the Wielkopolski National Park, were compared with data coming from the uninfected population in the Białowieża National Park (Kujawa-Pawlaczyk 1991). In infected populations a decrease in density began usually in May, while in healthy populations the beginning of the drop in density was observed not earlier than in June, and most often in July or August. Such a shift in time may not result only from climatic differences, thus they are explained by the effect of parasitic rust. The slope of curves does not show distinct differences in the populations with the presence of Puccinia komarovii and those without it.

The beginning of the decrease in the number of specimens and the appearance of the first peridea (Fig. 6), uredia and telia occurred almost simultaneously in all the experimental plots. Thus, the rate of infection was independent of the conditions, under which Impatiens parviflora developed in the oak-hornbeam forest and in the ecotone. The first plants died still with no visible symptoms of the fungus presence. The penetration of Puccinia komarovii into the host plants occurs during the germination of seedlings, whereas early symptoms of infection (visible peridea) were observed after approx. 2 months since the infection. Peridea appeared on plants already after the first specimens entered the generative stage; however, they were found solely on vegetative specimens. High mortality in May and in the first part of June pertained only to vegetative specimens. The specimens, which entered the flowering stage fast, did not die at that time. In successive months of vegetation, when Impatiens parviflora was in the generative stage, high losses of plants from the population were still observed.

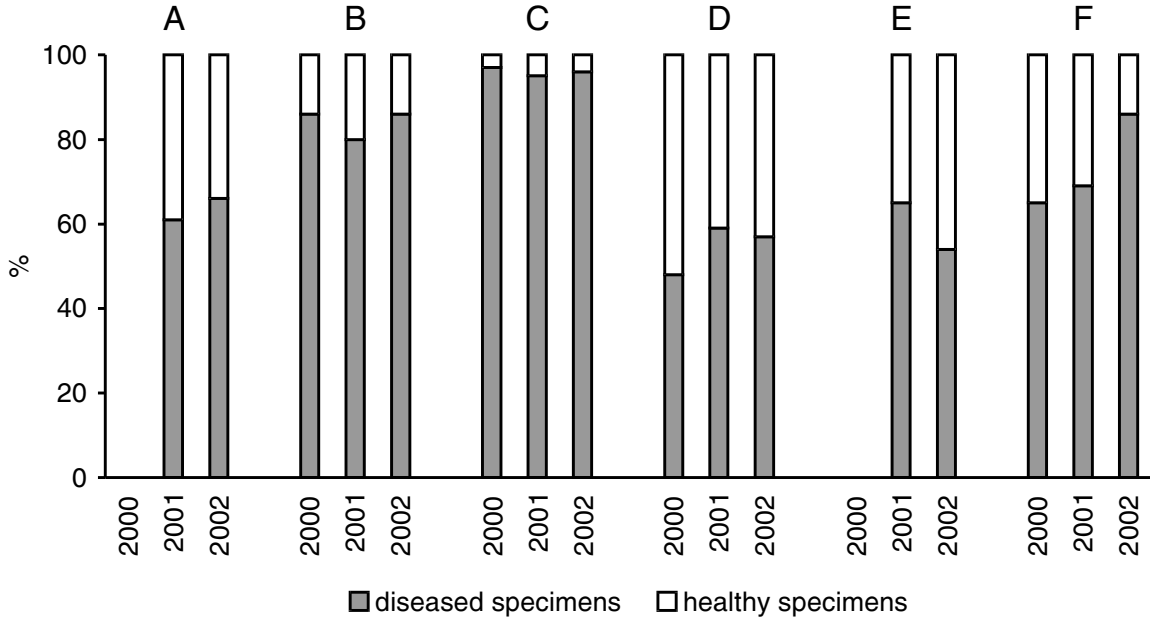

Fig. 3. The proportion of Impatiens parviflo$r a$ infected by Puccinia komarovii in the oakhornbeam (A-E) and the contact zone (F) in 2000-2002.

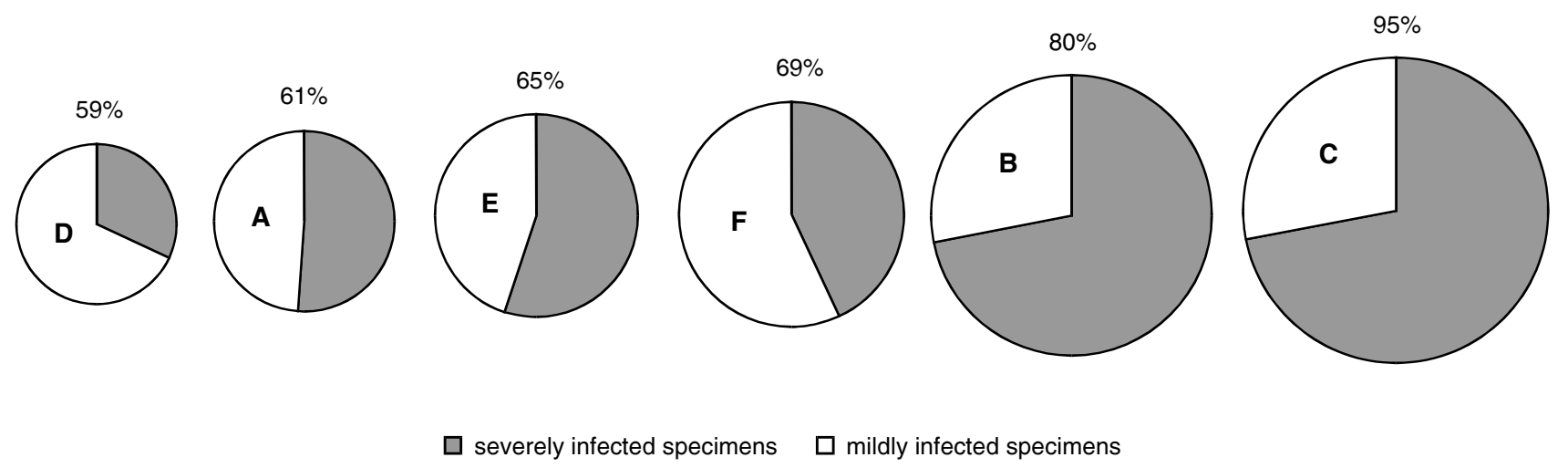

Fig. 4. The proportion of Impatiens parviflora infected by Puccinia komarovii and severity of infection. Circle diameter and\% value - participation of infected specimens in population; A-E - the oak-hornbeam; F - the contact zone. 

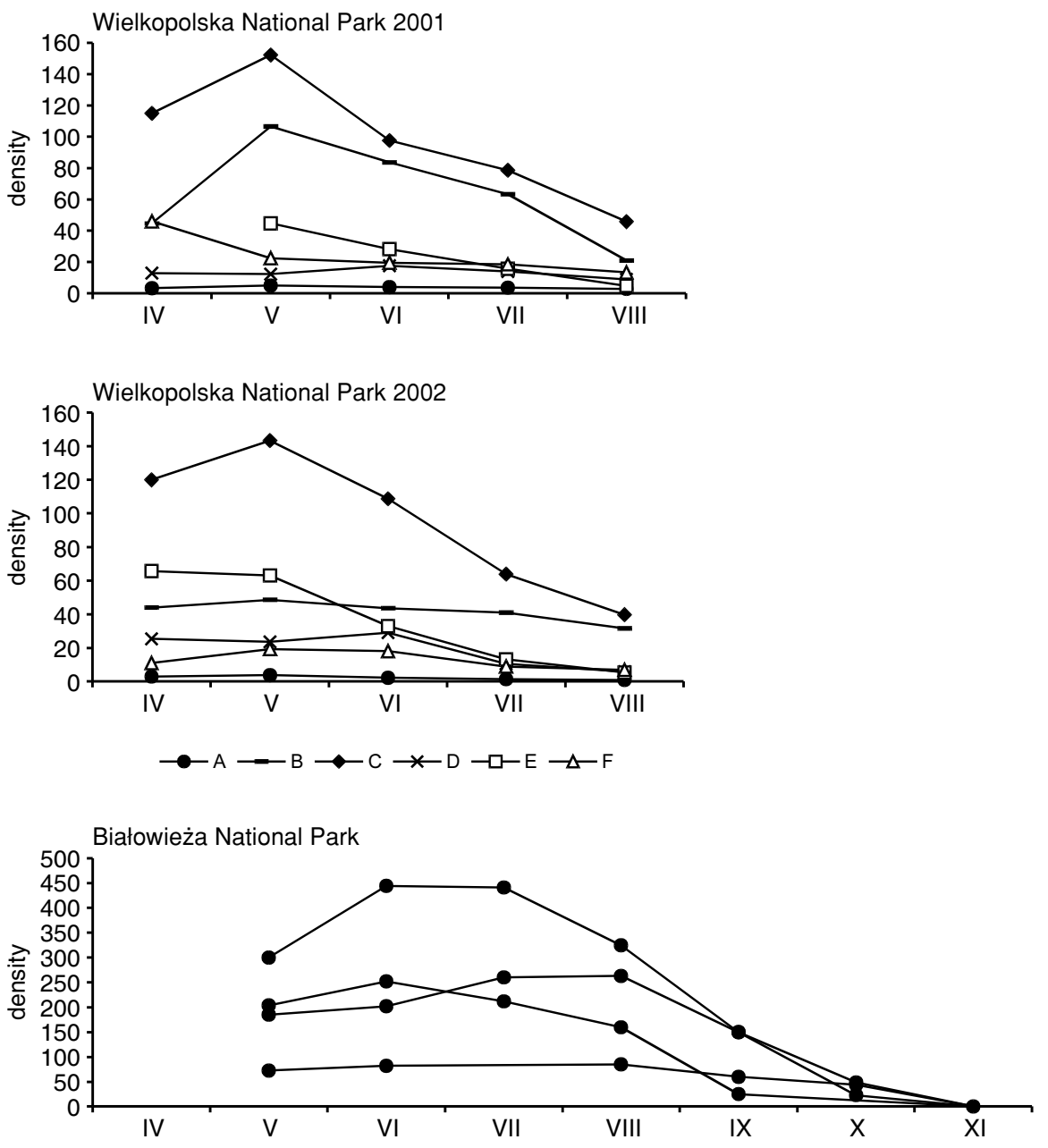

Fig. 5. Seasonal changes in the abundance of diseased Impatiens parviflora population (in Galio sylvatici-Carpinetum (A-E) and the contact zone (F), Wielkopolska National Park) and healthy population (in Tilio-Carpinetum, Białowieża National Park).

TABLE 2. The influence of Puccinia komarovii Tranzsch. infection on some vegetative features of Impatiens parviflora.

\begin{tabular}{|c|c|c|c|c|c|c|c|}
\hline Plant samples & & $\begin{array}{l}\text { Stem } \\
\text { length }\end{array}$ & $\begin{array}{l}\text { Hypocotyl } \\
\text { length }\end{array}$ & $\begin{array}{l}\text { Hypocotyl } \\
\text { diameter }\end{array}$ & $\begin{array}{l}\text { Stem length : } \\
\text { : Hypocotyl length }\end{array}$ & $\begin{array}{c}\text { Stem length : } \\
\text { : Hypocotyl diameter }\end{array}$ & Root system length \\
\hline \multirow{5}{*}{$\begin{array}{l}\text { Moderately shaded sites } \\
\text { healthy specimens }\end{array}$} & $\mathrm{x}$ & 19.41 & 7.92 & 0.41 & 2.61 & 47.28 & 4.23 \\
\hline & SD & 3.49 & 1.66 & 0.05 & 1.02 & 6.56 & 1.91 \\
\hline & $\mathrm{V}$ & 17.98 & 20.94 & 11.08 & 38.93 & 13.87 & 45.16 \\
\hline & $\operatorname{Max}$ & 25.7 & 11 & 0.5 & 6.39 & 61.04 & 8.5 \\
\hline & Min & 12.2 & 3.5 & 0.31 & 1.6 & 29.76 & 1.3 \\
\hline \multirow{5}{*}{$\begin{array}{l}\text { Moderately shaded sites } \\
\text { diseased specimens }\end{array}$} & $\mathrm{x}$ & 21.14 & 8.65 & 0.42 & 2.49 & 50.7 & 3.7 \\
\hline & SD & 4.2 & 1.36 & 0.06 & 0.59 & 7.29 & 2.36 \\
\hline & $\mathrm{V}$ & 19.89 & 15.7 & 15.16 & 23.67 & 14.37 & 63.89 \\
\hline & $\operatorname{Max}$ & 29.2 & 10.8 & 0.52 & 3.6 & 62.82 & 11.6 \\
\hline & Min & 7.4 & 5.8 & 0.3 & 0.94 & 23.13 & 1.4 \\
\hline \multirow{5}{*}{$\begin{array}{l}\text { Gaps in the tree stand } \\
\text { mildly infected specimens }\end{array}$} & $\mathrm{x}$ & 52.34 & 7.98 & 0.53 & 6.72 & 100.74 & 2.94 \\
\hline & SD & 5.04 & 1.23 & 0.08 & 1.28 & 11.79 & 1.47 \\
\hline & V & 9.63 & 15.38 & 15.49 & 18.99 & 11.7 & 50.17 \\
\hline & $\operatorname{Max}$ & 63.7 & 10 & 0.69 & 10.24 & 125.83 & 5.8 \\
\hline & Min & 39.4 & 4.9 & 0.39 & 4.15 & 77.94 & 0.9 \\
\hline \multirow{5}{*}{$\begin{array}{l}\text { Gaps in the tree stand } \\
\text { severely infected specimens }\end{array}$} & $\mathrm{x}$ & 51.73 & 8.01 & 0.5 & 6.52 & 105.64 & 3.35 \\
\hline & SD & 8.26 & 1.24 & 0.1 & 0.95 & 16.26 & 1.17 \\
\hline & $\mathrm{V}$ & 15.97 & 15.54 & 19.92 & 14.56 & 15.39 & 35.09 \\
\hline & Max & 70.8 & 11.3 & 0.73 & 8.52 & 136.75 & 5.8 \\
\hline & Min & 37.1 & 5.7 & 0.34 & 4.7 & 77.76 & 1.5 \\
\hline
\end{tabular}

The effect of the disease on the habit and biomass of balsam plants

The presence of the fungal infection and its intensity had an effect on the habit and biomass of small-flowered bal- sam. In infected specimens the length of the stem and hypocotyl increased by approx. 9\%, while the length of the root decreased by almost $13 \%$ in comparison to healthy plants (Table 2). The presence of the fungus did not change the 

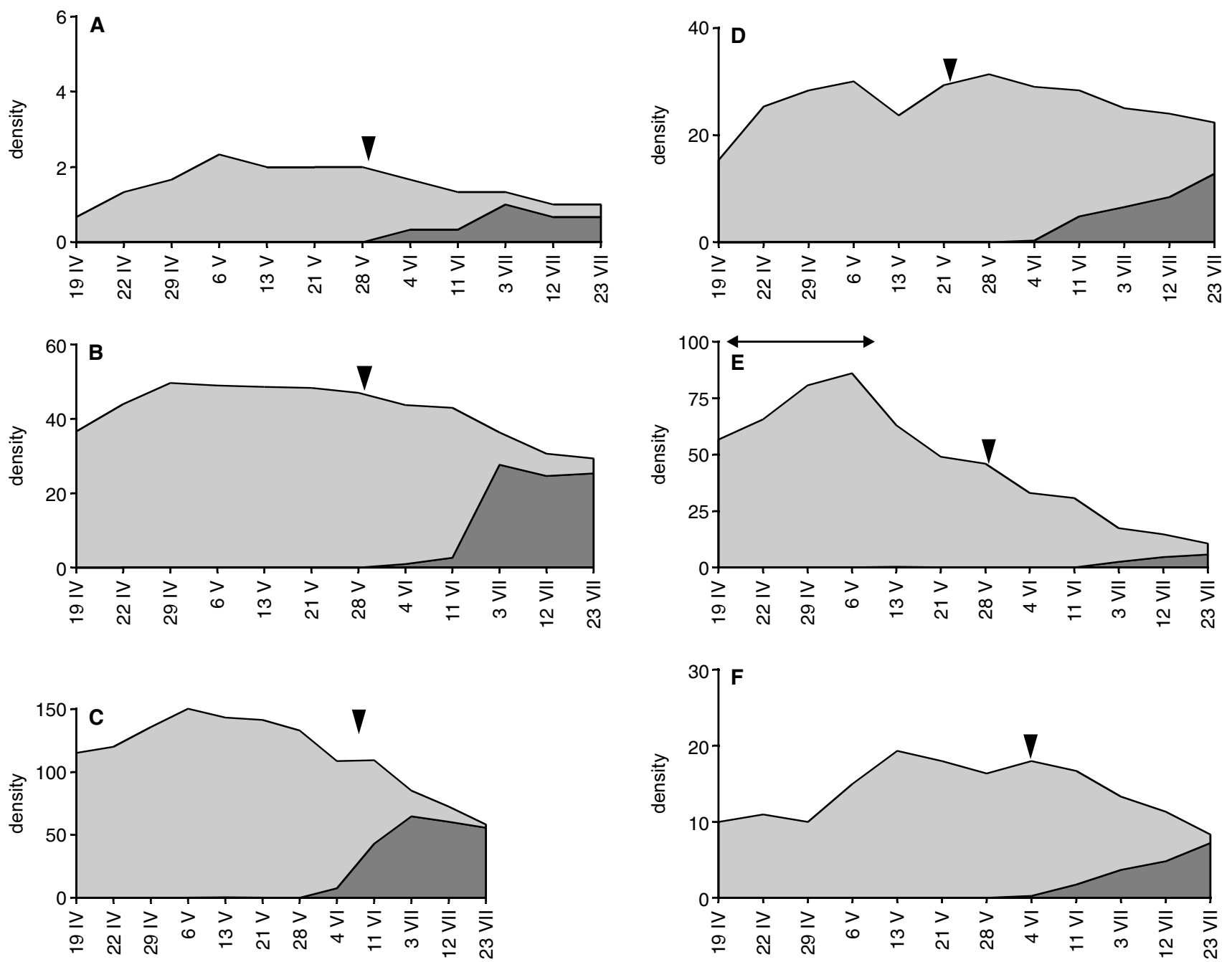

Fig. 6. Seasonal changes in Impatiens parviflora density and participation of infected specimens.

Grey colour - healthy specimens;

Black colour - diseased specimens;

$\boldsymbol{\nabla}$ - first flower buds on Impatiens parviflora;

$\leftrightarrow-$ the time of development of hornbeam seedlings leaves.

diameter of the hypocotyl. It was found that also in two groups of diseased specimens, i.e. in moderately and severely infected plants, the length of the hypocotyl increased along with the severity of the infection, but only by approx. $4 \%$. Both the presence of the fungus itself and the intensity of infection increased the dispersion of values for most analyzed metric traits. Infected specimens in comparison to uninfected ones and severely infected specimens in comparison to plants moderately infected had lower numbers of leaves, flowers and fruits. Although the fungus severely damages the surface of leaf blades (forming uredia and telia), the number of leaves decreased least significantly (Table 3).

Fresh weight of infected plants was by almost $30 \%$ lower in comparison to the weight of uninfected plants. The weight of severely infected plants decreased by $20 \%$ in comparison to the less severely infected balsam plants. In both investigated cases the weight of each weighed organ decreased (Table 3). The appearance of infection by itself decreased more considerably the total biomass and the biomass of all organs than it was found for the intensity of the infection. The weight of generative organs decreased most significantly, even by over $50 \%$. Under the influence of Puccinia komarovii activity the allocation of balsam biomass did not undergo considerable modifications. The reproduction effort expressed by the ratio of the weight of fruits to the total biomass showed a downward trend (Table 4).

\section{Non-specific defense reactions of Impatiens parviflora}

In response to fungal infection in the tissues of the host plant biochemical reactions are initiated, which lead to the formation of metabolites and structural barriers inhibiting the development of the pathogen. Non-specific defense reactions include e.g. increased peroxidase activity and the release of reactive oxygen forms. These compounds may be one of the first metabolites exhibiting a toxic action towards pathogen cells. A very important role among reactive oxygen forms is played by hydrogen peroxide $\mathrm{H}_{2} \mathrm{O}_{2}$, since - among other things - it initiates the hardening of cell walls (e.g. through their lignification).

Colour reactions showed an increase in 3.3-diaminobenzidine peroxidase and $\mathrm{H}_{2} \mathrm{O}_{2}$ and the lignification of cell walls in the vicinity of clusters of hyphae on leaves in balsam plants growing in all the experimental plots (Fig. 7). Additionally in each investigated case hydrogen peroxide was accumulated in vascular bundles found closest to disease spots. This compound might be transported by the ves- 
TABLE 3. The influence of Puccinia komarovii infection on Impatiens parviflora fresh biomass and biomass allocation.

\begin{tabular}{|c|c|c|c|c|c|c|c|c|}
\hline \multirow{3}{*}{ Plant parts } & \multicolumn{8}{|c|}{ Moderately shaded sites } \\
\hline & \multicolumn{4}{|c|}{ Healthy specimens } & \multicolumn{4}{|c|}{ Diseased specimens } \\
\hline & \multirow{2}{*}{$\begin{array}{c}\begin{array}{c}\text { Fresh } \\
\text { weight }[\mathrm{g}]\end{array} \\
1.478\end{array}$} & \multicolumn{2}{|c|}{$\begin{array}{c}\text { Biomass allocation } \\
{[\%]}\end{array}$} & \multirow[t]{2}{*}{ Number } & \multirow{2}{*}{$\begin{array}{c}\begin{array}{c}\text { Fresh } \\
\text { weight }[\mathrm{g}]\end{array} \\
0.87\end{array}$} & \multicolumn{2}{|c|}{$\begin{array}{c}\text { Biomass allocation } \\
{[\%]}\end{array}$} & \multirow[t]{2}{*}{ Number } \\
\hline Stem & & 48.2 & 41.1 & & & 41.5 & 34.3 & \\
\hline Leaves & 1.537 & 50.1 & 42.8 & 19.67 & 1.203 & 57.3 & 47.5 & 17.5 \\
\hline Flowers & 0.016 & 0.5 & 0.4 & 10.4 & 0.007 & 0.3 & 0.3 & 6.53 \\
\hline Fruits & 0.035 & 1.2 & 1.0 & 4.57 & 0.019 & 0.9 & 0.7 & 3.5 \\
\hline Above-ground total & 3.066 & 100 & & & 2.099 & 100 & & \\
\hline Roots & 0.527 & & 14.7 & & 0.435 & & 17.2 & \\
\hline Stand total & 3.593 & & 100 & & 2.534 & & 100 & \\
\hline Stem: root ratio & 2.8046 & & & & 2.0000 & & & \\
\hline
\end{tabular}

\begin{tabular}{|c|c|c|c|c|c|c|c|c|}
\hline \multirow{3}{*}{ Plant parts } & \multicolumn{8}{|c|}{ Gaps in the tree stand } \\
\hline & \multicolumn{4}{|c|}{ Mildly infected specimens } & \multicolumn{4}{|c|}{ Severely infected specimens } \\
\hline & \multirow{2}{*}{$\begin{array}{c}\begin{array}{c}\text { Fresh } \\
\text { weight }[\mathrm{g}]\end{array} \\
4.22\end{array}$} & \multicolumn{2}{|c|}{$\begin{array}{c}\text { Biomass allocation } \\
{[\%]}\end{array}$} & \multirow[t]{2}{*}{ Number } & \multirow{2}{*}{$\begin{array}{c}\begin{array}{c}\text { Fresh } \\
\text { weight }[\mathrm{g}]\end{array} \\
3.596\end{array}$} & \multicolumn{2}{|c|}{$\begin{array}{c}\text { Biomass allocation } \\
{[\%]}\end{array}$} & \multirow[t]{2}{*}{ Number } \\
\hline Stem & & 65.8 & 59.0 & & & 71.6 & 62.9 & \\
\hline Leaves & 1.993 & 31.1 & 27.9 & 17.8 & 1.297 & 25.8 & 22.7 & 17.7 \\
\hline Flowers & 0.02 & 0.3 & 0.3 & 10.8 & 0.016 & 0.3 & 0.3 & 9.07 \\
\hline Fruits & 0.179 & 2.8 & 2.5 & 8.6 & 0.11 & 2.3 & 2.0 & 6.3 \\
\hline Above-ground total & 6.412 & 100 & & & 5.019 & 100 & & \\
\hline Roots & 0.735 & & 10.3 & & 0.696 & & 12.2 & \\
\hline Stand total & 7.147 & & 100 & & 5.715 & & 100 & \\
\hline Stem: root ratio & 5.7415 & & & & 5.1667 & & & \\
\hline
\end{tabular}

TABLE 4. The influence of Puccinia komarovii infection on reproduction effort of Impatiens parviflora.

\begin{tabular}{lcc}
\hline \multirow{2}{*}{ Plant samples } & \multicolumn{2}{c}{ Reproduction effort } \\
\cline { 2 - 3 } & Flowers + fruits biomass / total biomass [\%] & Fruits biomass / total biomass [\%] \\
Moderately shaded sites & 1.42 & 0.97 \\
- healthy specimens & 1.03 & 0.75 \\
- diseased specimens & & 2.50 \\
\hline Gaps in the tree stand & 2.78 & 1.92 \\
- mildly infected specimens & 2.20 & \\
- severely infected specimens & & \\
\hline
\end{tabular}

sels to other parts of the leaf and deposited for a longer period of time in thickened cell walls of vessels adjacent to necrotic spots.

Investigations did not show significant differences in the intensity of biochemical response to rust in plants which developed under various conditions. Thus, it may be assumed that the environmental factor in this case has no effect on the strength of defense mechanisms. The intensity of response depends on the degree of infestation in plants - it is distinctly stronger in plants with more severe disease symptoms. In this group of plants the products of colour reactions could cover even as much as $75 \%$ leaf blade area.

\section{DISCUSSION AND CONCLUSIONS}

Infection and development of diseases caused by rust accelerates dying off of plants, which in the oak-hornbeam forests of the Wielkopolska National Park begins at the turn of April and May. In that period the loss is slight, when compared to the data reported by Bacigálowa et al.
(1998) and Eliáš (1995), according to which the mortality of juvenile specimens may reach $100 \%$. In infected specimens the length of the stem and hypocotyl increases, while the number of leaves, flowers and fruits decreases. Gold and Caldwell (1989) stated that defoliation might cause an increased photosynthesis rate, which is manifested by a faster growth rate in specimens subjected to defoliation. However, not always is such a dependency observed between the number of leaves and the increase in photosynthesis rate. According to Chester (1946), the damage and loss of leaves caused by the presence of a parasitic fungus lowers the photosynthetic capacity of a plant. As a result of the incidence of infection and along with its intensity, the reproduction effort of Impatiens parviflora decreased by approx. $23 \%$. Studies by Harper and Ogden (1970) showed that the reproduction effort of a population may fluctuate in natural conditions within the $20-30 \%$ range. In relation to the above, it must thus be stated that the presence of a parasitic fungus lowers the total biomass, but it does not have a significant effect on the decrease in energy expenditure on the production of fruits and seeds. 

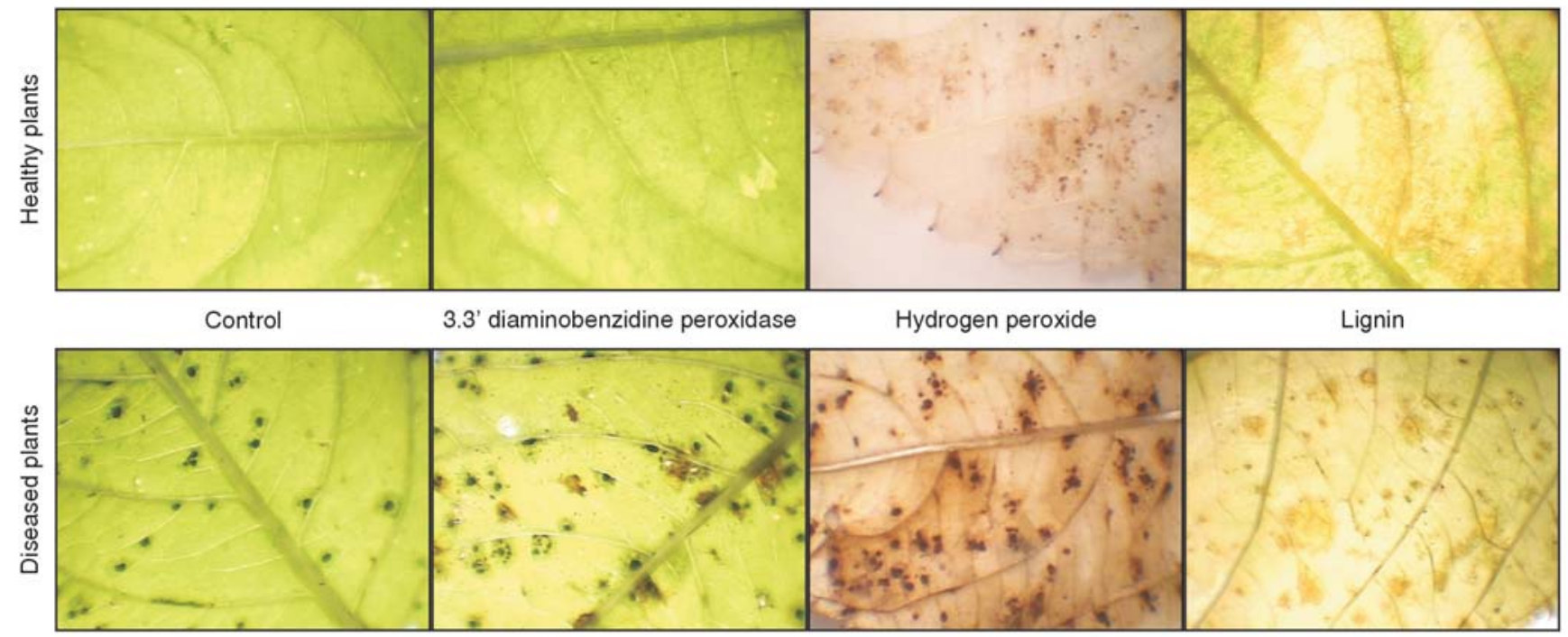

Fig. 7. $\mathrm{H}_{2} \mathrm{O}_{2}$ accumulation, 3.3' diaminobenzidine peroxidase activity and the lignification of cell walls in healthy and diseased Impatiens parviflora.

The method of Impatiens parviflora control, applied so far, consisted in the uprooting or cutting of plants, and turned out to be quite effective; however, they had to be continued for at least 10 years (Adamowski, Keczyński 1998). Since on the European continent Puccinia komarovii parasitizes solely on small-flowered balsam, Eliáš (2001) was considering the feasibility of using this species as a biological control agent in case of balsam plants. This study indicates that in oak-hornbeam forest, characterized by a diverse mosaic-patch structure, the intensity of the disease and the mortality of specimens growing in individual patches differ considerably. For this reason it seems that it is impossible to eliminate balsam completely. Areas in which plants are less infected may constitute natural gene reserves for the survival and reconstruction of the population. Long-term observations of the demography of an infected population need to be conducted to verify this hypothesis.

Experiments connected with biological control have not always been successful (Mierzejewska 2000), thus studies need to be carried out to gain more insight into the relation between both species, particularly on the biochemical level.

\section{ACKNOWLEDGEMENT}

We wish to thank Dr hab. Jolanta Floryszak-Wieczorek for her help in selecting the methods used to study Impatiens parviflora resistance mechanisms.

This investigation was partially supported by the State Committee for Scientific research $(\mathrm{KBN})$, Grant No. 3 P04G 05224.

\section{LITERATURE CITED}

ABRAHAMSON W.G., HERSHEY B.J. 1977. Resource allocation and growth of Impatiens capensis (Balsaminaceae) in two habitats. Bull. Torrey Bot. Club 104: 160-164.

ADAMOWSKI W., KECZYŃSKI A. 1998. Czynna ochrona zbiorowisk leśnych Białowieskiego Parku Narodowego przed wkroczeniem Impatiens parviflora. Parki Nar. Rez. Przyr. 17 (1): 49-55. Białowieża. in Polish with English summary)
BACIGÁlOVÁ K., ELIÁŠ P., ŠROBÁRÓVA A. 1998. Puccinia komarovii - a rust fungus on Impatiens parviflora in Slovakia. Biologia 53, 1: 7-13. Bratislawa.

BACIGÁLOVÁ K., ZLOCHOVÁ K. 2001. Invázne mikroskopické huby. Život. Prostr. 35 (2): 96-97. (in Czech)

BUHR H. 1964. Bestimmungstabellen der Gallen (Zoo- und Phytocecidien) an Pflanzen Mittel- und Nordeuropas. 1 Band. Veb Gustav Fisher Verlag. Jena.

BURDON J.J. 1987. Disease and Plant Population Biology. Cambridge University Press, Cambridge.

CHESTER K.S. 1946. The nature and prevention of the cereal rusts as exemplified in the leaf rust of wheat. Waltham, Mass. USA. Chronica Botanica Company. 269 pp.

CLAY K. 1990. Comparative demography of three graminoids infected by systemic, clavicipitaceous fungi. Ecology 71 (2): 558-570.

DAUMANN E. 1967. Zur Bestäubungs - und Verbreitungsökologie dreier Impatiensarten. Preslia 39.

ELIÁŠ P. 1995. Stem fungi disease (Puccinia komarowii) on Impatiens parviflora in Slovakia: effects on population dymanics and its role in regulation of plant populations. Carinthia II, Sonderheft, 53: 14-16.

ELIÁŠ P. 2001. Puccinia komarovii as a biological control agent of an invasive plant - effects on population dynamics of Impatiens parviflora. $6^{\text {th }}$ International Conference Ecology and Management of Alien Plant Invasions. EMAPi Loughborough University, UK. $1 \mathrm{~s}$.

HEGI G. 1965. Ilustrietre Flora von Mittel-Europa. - Carl Hanser Verlag, München, 5 (1) 677 pp.

GOLD W., CALDWELL M.M. 1989. The effects of the spatial pattern of defoliation on regrowth of tussock grass. II Canopy gas exchange. Oekologia 81: 437-442.

HARPER J.L. 1977. Population Biology of Plants. Academic Press, London.

HARPER J.L., OGDEN J. 1970. The reproductive strategy of higher plants. I. The concept of strategy with special reference to Senecio vulgaris L. J. Ecol. 58: 681-698.

JOSEPH C.A. 1929. The plant rusts (Uredinales). John Wiley \& Sons, Inc. London: Chapman and Hall. 446 pp.

KUJAWA-PAWLACZYK J. 1991. Rozprzestrzenianie się i neofityzm Impatiens parviflora DC. w Puszczy Białowieskiej. Phytocoenosis 3 (NS) Semin. Geobot. 1: 213-222. (in Polish with English summary)

LEMBICZ M. 1996. Demograficzne skutki wystepowania pasożytniczego grzyba Epichloë typhina (Ascomycetes) w popula- 
cjach Puccinellia distans. Fragm. Flor. Geobot. 3: 389-394. (in Polish with English summary)

MAJEWSKI T. 1979. Flora Polska, Grzyby (Mycota) 11 Uredinales II. PWN Warszawa. 462 pp.

MIERZEJEWSKA E. 2000. Ekologiczne manipulacje w ochronie i zwalczaniu różnych organizmów. Wiad. Ekol. 46 (4): 283-294. (in Polish with English summary)

MILOSEVIC M., SLUSARENKO A.J. 1996. Active oxygen metabolism and lignification in the hypersensitive response in bean. Physiol. Mol. Plant Pathol. 49: 143-158.

PAŃKA D. 2004. Badania nad endofitami rodzaju Neotyphodium występującymi w trawach w Polsce. Materiały z Konferencji Jubileuszowej Choroby Roślin na tle środowiska. PTF - AR Poznań - KNL PAN, str. 160. (in Polish)

SCHMITZ G. 1998. Impatiens parviflora DC. (Balsaminaceae) as neophyte in Central European forests and woodland - a bizonal analysis. Z. Ökol. Naturschutz. 7 (4): 193-206.

STARY P., LASKA P. 1999. Adaptation of native syrphid files to new exotic plant (Impatiens spp.)-aphis-ant assocations in Central Europe (Dipt., Syrphidae; Hom., Aphididae; Hym.,
Formicidae). Anzeiger für Schadlingskunde - J. Pest Sci. 72 (3): 72-75.

Savich V.P. 1957. Cryptogamic plants of the USSR. 4. Izdatelstwo Akademii Nauk SSSR, Moskwa-Leningrad.

STACHERSKA B. 1972. Impatientinum asiaticum Nevsky (Homoptera, Aphididae) - a species new to the Polish fauna. Polskie Pismo Entomologiczne. Bulletin Entomologique de Pologne. 42 (3).

SYDOW P. SYDOW H. 1904. Monographia Uredinearum seu specierum omnium ad hunc usque diem descripto et adumbratio systematica. 1. Genus Puccinia, Lipsiae, Fratres Borntraeger, 972 pp. (in Latin)

THORDAL-CHRISTENSEN H., ZHANG Z., WEI Y., COLLINGE D.B. 1997. Subcellular localization of $\mathrm{H}_{2} \mathrm{O}_{2}$ in plants. $\mathrm{H}_{2} \mathrm{O}_{2}$ accumulation in papillae and hypersensitive response during the barley-powdery mildew interaction. Plant J. 11 (6): 1187-1194.

TREPL L. 1984. Über Impatiens parviflora DC. als Agriophyt in Mitteleuropa. Diss. Bot. 73: 1-400. 